\title{
Die eise aan die gereformeerde prediking in die teenswoordige kultuur van verandering
}

\author{
J.M. Vorster \\ Departement Ekklesiologie \\ HTS/PU vir CHO \\ POTCHEFSTROOM
}

\begin{abstract}
Modern culture has been defined as a culture of change. In South Africa the present process of change across the broad spectrum of modem life is evident. This reality poses new challenges for Reformed preaching. In this article the major aspects of the new challenges are analysed from a futurological and sociological point of view. Attention is paid to changes in moral standards, secularization, the emancipation of Christian faith in the post-apanheid era, the loss in function and authority of the Church and the decline in ecclesiastical commitment of Christians. The severe influence of the cybemetic revolution and future shock is also discussed with reference to their effect on Christian faith and Reforned preaching.

In conclusion a few guidelines are fonnulated from an evangelistic perspective: in this regard the concepts of false and true authority, contextuality in the preaching and communication are discussed. These guidelines focus on improving the effectiveness of Reformed preaching in the present culture of change.
\end{abstract}

\section{IMMANENTISME EN KRITISISME}

Die wêreld van die laaste dekades van die twintigste eeu word gekenmerk deur 'n kultuur van verandering. Daarmee word bedoel dat grondliggende beginsels wat vir baie eeue die koers van die menslike denke en lewe bepaal het ingrypend gewysig word. In 1964 het Rossman (1968:1) reeds gesê: "Change is the name of our age". Hy het met dié stelling die vernaamste kenmerk van die moderne Westerse jeugkultuur beskryf. Sy stelling kan egter nou van toepassing gemaak word op die hele leefwyse van die moderne mens. "Change" is ook nie net 'n werklikheid waaraan die mens willoos onderhewig is nie maar dit is 'n doelbewuste strewe van die moderne mens. Hierdie doelbewuste soeke na verandering kan met reg beskou word as die wesensbepalende tendens van die moderne kultuur (Vorster, 1981a:214).

Onderliggend aan die drif tot deurlopende verandering lê twee basiese geestes- en denkbenaderings. Hierdie benaderings kan onder woorde gebring word met die terme immanentisme en kritisisme (Vorster, 1981:215). Met immanentisme word bedoel dat die mens se belangstelling wegbeweeg het van ' $n$ eskatalogie of ' $n$ utopiese ideaal en dat hy besig wil wees met die hier en nou. Die futuroloog Polak (1958:18) het reeds in die vyftigerjare hierdie benadering raakgesien en dit beskou as ' $n$ ingrypende ver- 
andering in die lewenswyse van die mens. Hy dui aan dat kultuur in die verlede gedra is deur positiewe toekomsverwagtings. Vir die Christen het die eskatalogiese verwagting gelei tot 'n 'synsoptimistiese kultuur' wat gerig is op die wederkoms en God se vernuwing van alle dinge. Vir die humanis het 'n utopiese verwagting gelei tot 'n 'wilsoptimistiese kultuur' wat gerig is op die opbou van 'n nuwe wêreld, beplan en gebou deur die mens. In albei hierdie verwagtingswyses het daar verandering gekom. Die eeue-oue verwagtinge is vervang met hede-gerigtheid en saaklikheid oor die sake van die huidige tydsgewrig. In die teologie is hierdie benadering versterk deur invloedryke teoloë soos Bultmann (1967:25), Bonhoeffer (1960:III:104); Hamilton (1966:49); Robinson (1964:100) en Sölle (1965:145) en het dit uiteindelik gelei tot die baie politieke teologiese strominge van die moderne tyd (Fierro, 1977:48). Hierdie strominge poog om relevante teologie te bedryf teen die agtergrond van 'n paradigma wat radikaal verskuif.

Kritisisme is die logiese parallel van immanentisme. Dié begrip beskryf die geweldige kritiese instelling wat die mens begin openbaar het ten opsigte van die bestaande orde. Omdat sy kultuur nie meer gemanipuleer word jeur die droombeelde van die toekoms nie en hy meer ingestel is op die eise en nood van sy omgewing, kyk hy krities na die bestaande orde. Hy word sensitief vir die supervraagstukke van die hede. Tradisionele waardes, instellinge en gedragspatrone word krities bejeën. In die Christendom het hierdie kritisisme ook sake soos Christelike moraal, geloof, prediking en die kerk onder die soeklig geplaas. Niks ontglip meer die ontleedmes van die moderne mens nie.

As die antwoord nie meer gevind word in die droombeelde van die toekoms of in die resultate van tradisie en geskiedenis nie, ontstaan die vraag waar die oplossing lè. Voortdurende verandering word dan as moontlike oplossing gesien. Nie die toekoms of die bestaande realiteit bied hoop vir die mens nie maar slegs die realiteit van 'n deurlopende veranderingsproses. Die filosoof Bloch (1970:1-9) het die aandag op hierdie oplossing gevestig. Gegrond op sy bekende stelling: "Wat is kan nie waar wees nie" (Bloch, 1961:65) het hy gepleit vir verandering nie as 'n middel tot 'n doel nie, maar as doel op sigself. Die deurlopende verandering bied hoop aan noodlydendes en verdruktes. In die teologie het hierdie antwoord wat Bloch bied, neerslag gevind in Moltmann (1967) se Teologie van die Hoop.

Verandering het inderdaad die naam van die gees van die moderne tyd geword. Die gereformeerde prediker en prediking vind homself in hierdie milieu. Die kultuur van verandering skep 'n nuwe konteks waarin die prediking Skrifwaarhede aktueel moet toepas. Om effektief te preek sal die eise van hierdie konteks ontleed en beantwoord moet word. Die waarde en noodsaak van kontekstualiteit in die bediening is immers in die teologie reeds aangedui (Hesselgrave, 1989; DeWaard, 1990:4). Baie aspekte van hierdie nuwe konteks kan bespreek word. In hierdie artikel word egter net stilgestaan by dit wat van belang is vir die gereformeerde prediking in Suid-Afrika vandag. 
Die bedoeling is om vanuit die Futorologie en Sosiologie die belangrikste tendense en die moderne Suid-Afrikaanse kultuur aan te toon met die eise wat dit stel aan die gereformeerde prediking. Daarom is die toespitsing hierin op bronne in hierdie verband en nie soseer op bronne oor die Homiletiek nie.

Die volgende temas word dus verder bespreek: die verskuiwing in moraal, die ontvoogding van die Christelike geloof; die funksie-, gesags-, en meelewingsverlies van die kerk, toekomsangs en introversie en die kubernetiese rewolusie. Daarna word enkele riglyne aangebied vir die prediking van vandag vanuit 'n evangeliese perspektief.

\section{DIE VERSKUIWING IN MORAAL}

Suid-Afrika deel in die moderne wêreldwye kultuur van verandering. Die golf wat Europa en die VSA reeds in die sestigerjare getref het, spoel nou oor die Suid-Afrikaanse gemeenskap. Internasionale kontak en kommunikasie het die moontlikheid van isolasie en selfbeskerming feitlik vernietig. Uit 'n Christelike oogpunt beskou, laat die kritisisme teen die Christelike geloof en die gevolglik sekularisasieproses nou ook sy invloed hier geld. Edwards (1987:285) sê: "It has often been predicted that Europe will become completely secular and that the rest of the world will end up like it." SuidAfrika is geen uitsondering nie.

Soos in Europa is moraal in Suid-Afrika bepaal deur 'n Christelike kultuuretos. Die kulturele invloed in die koloniale tydperk en die bydraes deur die sendingarbeid van die Calvinisme, Rooms-Katolisisme en ander Protestantse rigtings het hiertoe bygedra. Hierdeur het 'n Suid-Afrikaanse Christendom as dominante kultuurstroming tot stand gekom. Hoewel ander godsdienste ook in Suid-Afrika figureer, is die algemene moraal in sake soos onderwys, huwelik, staatkunde, lewenstyl en maatskaplike lewe vanuit die Christendom bepaal. Met die bevoorregting van 'n bepaalde vorm van Calvinisme deur die apartheidsstelsel sedert 1948 is die invloed van hierdie vorm van Christendom nog meer versterk. Onder invloed van die Afrikaanse kerke het die owerheid selfs die taak van beskermheer van die Calvinistiese moraal op hom geneem.

Algaande het die erosie van die veranderingskultuur sy invloed op hierdie kultuuretos laat geld. So byvoorbeeld het die gees van seksuele vryheid tradisionele instellings soos huwelik en gesin aangetas - 'n verskynsel wat reeds vroeër in Europa waargeneem is. Wat Runia (1978:91) in 1978 hieroor van Nederland geskrywe het, geld vandag vir Suid-Afrika. In elke huis kan tans op televisie gekyk word na tallose vrye seksuele verhoudings wat in ontspanningstories as normaal en gangbaar voorgestel word. Die kind leer ' $n$ bepaalde morele kode in die prediking en hy ervaar ' $n$ ander kode in sy daaglikse lewe. Die afstand tussen prediking en katkisasie aan die een kant en die lewe aan die ander kant word groter. Die kind beland in die dilemma dat hy 'n keuse moet maak, en moet besluit of hy moet kies vir die etiese beginsels soos hy dit 'kerklik' geleer het en of hy moet kies vir die druk van sy moderne omgewing. Juis hier praat 
die invloed van die sekularisasieproses hard. Die moderne mens laat hom 'leef deur sy omgewing, ten spyte van die feit dat hy bewustelik daarteen sou wou kies. Hy 'asem'onvermydelik 'n nuwe gees in. Onder druk van die 'groot wèreld' word hy ingesuig in 'n nuwe moraal waarin nie die Bybel nie, maar die mens se behoeftes self, die norm is.

Benewens die verskuiwing in seksuele moraal kan daar ook baie ander terreine aangedui word waar die Christendomlike kultuuretos opsy geskuif word. In die beroepsetiek het materiële voordele roeping verdring en die ontwikkeling van gawes en talente moet opsy staan vir die aanvraag uit die wetenskap en tegniek. In die mediese etiek het die begrip 'lewe' onder die soeklig gekom en is die Christen gekonfronteer met beslissinge oor aborsie en genadedood as antwoord op 'n grootskaalse verandering in openbare houding hieroor (Stott, 1984:281). Voorts het die romantisering van politieke en reaksionêre geweld toenemend nuwe vrae aan die Christelike politieke etiek begin stel en moes kerke hulleself opnuut daaroor verantwoord (Hulley, 1990:67).

Hierby kan gevoeg word die eise wat internasionale supervraagstukke aan die Christendom in Suid-Afrika stel soos die kernvraagstuk, die ekologie, bestryding van vigs, rykdom en armoede, menseregte, industriële verhoudinge en feminisme. Die ou antwoorde hanteer nie meer hierdie nuwe probleme nie en oral word Christelike bediening en leierskap voor nuwe uitdagings gestel (Stott, 1984:327).

Vir die Christen en vir die prediking word alles teruggevoer na die enkele vraag: Moet die houding van die Christen akkommoderend of konfronterend wees? Moet die gelowige deur die prediking in die nuwe moraal ingelei word tot aanvaarding van byderwetse norme of moet hy gesterk word in 'n alternatiewe lewensmodel. Die gereformeerde prediking en bediening het tradisioneel die konfrontasie en dikwels wêreldmydingsmodel gekies. Die neiging in die huidige Christelike etiek is tans om die nuwe moraal te akkommodeer. Edwards (1987:354) gee hiervan 'n sprekende voorbeeld wanneer hy sê: "For us, the tolerance of people in different life-situations has become an important part of morality." Die keuse tussen konfrontasie en akkommodasie is die kernsaak waarmee die gereformeerde kerke tans dwarsoor die wêreld worstel. Die debat oor hermeneutiek en etiek in die Gereformeerde Ekumeniese Raad is hiervan 'n sprekende voorbeeld (Gertformeerde Ekumeniese Sinode, 1988:460). Die gereformeerde prediker in Suid-Afrika is in die plaaslike gemeente gekonfronteer met juis hierdie probleem. Hoe moet vir mense gepreek word wat reeds beïnloed word deur die nuwe moraal? Hierop word later teruggekom.

\section{DIE ONTVOOGDING VAN DIE CHRISTELIKE GELOOF}

Die Christelike geloof en in besonder die Calvinisme, het in Suid-Afrika besondere beskerming geniet. Onder ' $n$ bepaalde indruk en interpretasie van artikel $36 \mathrm{NGB}$ het die Afrikaanse Kerke van die owerheid verwag om die Christelike godsdiens te bevorder en Christelike moraliteit te beskerm. Owerheidsbeleid oor menseverhoudinge, 
huwelik, gesin, onderwys, seksuele moraal en persvryheid is sterk deur die kerke begelei (Heyns, 1991:172). Voorts is die staatsbeheerde media tot beskikking van die Christelike kerke gestel vir die opbou en bevordering van die Christelike geloof. Die onderwysstelsel in Suid-Afrika is ook sedert 1967 beskou as 'n stelsel van 'Christelike onderwys'. Met reg kan dus beweer word dat die Christelike geloof gestaan het onder voogdyskap van die staat.

Hierdie situasie het vir kerke en die prediking bepaalde implikasies ingehou. Ten opsigte van morele norme het die owerheid die kultuur met wetgewing bepaal - 'n feit wat daartoe gelei het dat kerklike getuienis en prediking veelal die owerheid verantwoordelik gehou het vir die handhawing van Christelike moraliteit. Kerke het in hierdie opsig 'n oop deur tot die owerheid gehad. Die gevolg was dat mense se sedes merendeels deur wetgewing van buite bepaal en gereglementeer is, sonder dat dit gepaard gegaan het met innerlike oortuiging. Kerke het byvoorbeeld van die owerheid verwag om onsedelikheid te weer, die Sondag te heilig, dobbelary te keer ensovoorts. Ten spyte hiervan het 'n morele verskuiwing in die lewe van Christene plaasgevind.

Met die ontwikkeling van 'n nuwe konstitusionele bedeling in Suid-Afrika is dit duidelik dat die Christelike geloof in sy verhouding tot die owerheid 'ontvoog' gaan word. Die konsekwente toepassing van die beginsel van godsdiensvryheid gaan die bevoorregting van die Christelike geloof beëindig, want ander godsdienste sal ook gelyke moontlikhede ontvang. Die kerke sal dus nie meer van die owerheid kan verwag om Christelike sedes te beskerm en uit te bou nie.

Wat gaan die implikasies hiervan wees? Wie vashou aan die ou model verwag 'n onvermydelike sekularisasieproses (Gereformeerde Kerke in Suid-Afrika, 1991:9). Myns insiens sal dit egter nie die grootste implikasie wees nie, omdat die verskuiwing in moraal oor die afgelope dekades plaasgevind het ondanks die beskerming van Christelike moraal deur die staat. Die owerheid kan sekularisasie deur middel van wetgewing nie stuit nie omdat die kragte van die moderne kultuur van verandering te groot is. 'n Veel groter implikasie is die trauma wat sekularisasie gaan inhou vir die Christen. Wanneer sy beskerming 'van buite' verval, sal hy moet steun op die krag van innerlike oortuiging. Die vraag ontstaan dan of daardie oortuiging sterk genoeg is wanneer die Christen self moet sensuur toepas in sy huis, self die Sondag moet heilig en positief Christen moet wees tussen ongeloof en ander gelowe.

Die ontvoogding van die Christelike geloof stel gewigtige eise aan die prediking van vandag. Die prediker het te doen met 'n groot gemeenskap van Christene wat nie werklik weet of gemotiveer is om die spel van Christen-wees te speel nie: hulle is moreel verward en vervreem van die tradisionele Christelike kultuuretos. Wat Kritzinger (1991:106) en Mkhatshwa (1991:117) sê ten opsigte van die ideologiese invloede op kerke in Suid-Afrika is in 'n ruimer sin waar. Hulle meen dat daar 'n 'herevangelisasie' van kerke moet plaasvind om ideologiese reste uit te suiwer. Dit lyk egter 
noodsaaklik dat die 'herevangelisasie' die trauma van die ontvoogde Christene ook in behandeling sal moet neem. Christene sal moet leer om op hulle eie geloofsbene te staan en om in elke situasie die beginsels van die Bybel konkreet en effektief toe te pas. In hierdie herevangeliseringsproses staan die prediking sentraal.

\section{DIE FUNKSIE-, GESAGS- EN MEELEWINGSVERL IES VAN DIE KERK}

Die kultuur van verandering het wêreldwyd 'n verlies vir die kerke meegebring. Die vervanging van die Christendomlike moraal deur die moderne sekulêre lewenswyse van immanentisme en kritisisme het die invloedsfeer van kerke kleiner gemaak. Hierdie tendens is reeds enkele dekades gelede in Europa nagevors. Die sosioloog Dekker (1971:39) het toe al vasgestel dat kerkwees en kerklike betrokkenheid al hoe minder mense interesseer. Soortgelyke onlangse ondersoeke in Suid-Afrika bring dieselfde tendense aan die lig (Hendriks, 1986:72).

Die 'verlies' openbaar homself op drie vlakke van kerk-wees naamlik 'n verlies aan funksie, gesag en meelewing (Vorster, 1981:3). Die uitdrukking funksieverlies van die $k e r k$ is ' $n$ beskrywing van die tendens waarin kerke baie van hulle tradisionele funksies en aktiwiteite nie meer vervul nie. Hierdie funksieverlies kan op verskeie vlakke aangetoon word. Die kerklike diakonaat het verskraal en barmhartigheid is in die moderne samelewing grotendeels oorgeneem deur die staat of privaat inisiatief. Sielkundige dienste neem die plek in van pastorale bediening en al hoe meer gelowiges wend hulle eerder tot die sielkundige as die predikant. Die meriete van sielkundige ondersteuningsdienste word nie hier prinsipieel beoordeel nie; die tendense word genoem om te illustreer dat wat vroeër die aksieveld van kerke was, nou daaruit verdwyn. Die funksieverlies van die kerk lei noodwendig ook tot 'n funksieverlies van die prediker: die predikant het eenvoudig nie meer dieselfde 'status' as vroeër nie. Hy het nuwe kwellinge waarvan die grootste die gevoel van identifikasie en oneffektiwiteit is (Vosloo \& Bisschoff, 1989:564). Hierdie kwelpunte het noodwendige gevolge vir die prediking soos blyk uit die groot verskeidenheid bedieningsmetodes wat tans beproef word in 'n poging om meer funksioneel te wees.

Die gesagsverlies is die gevolg van die moderne tendens wat Stott (1982:50) noem "the anti-authority mood". Volgens hom word alle gesagsinstellinge vandag uitgedaag "as result of the self-conscious revolt against authority". Selfs die gesag van die Woord is in die gedrang. Die mens staan krities teenoor dit wat met bepaalde hoër gesag aan hom oorgedra word. Ook die kerk het gesag ingeboet: pouslike en kerklike uitsprake het nie meer die effek van vroeër nie. Dieselfde gees bedreig die gesag van die prediking. Preke word nie meer vir 'soetkoek' opgeëet nie en ex catedra-uitsprake van predikante en sogenaamde kerkleiers word lank nie meer gesien as die laaste woord nie.

Die uitdrukking meelewingsverlies beskryf die afname in gelowiges se betrokkenheid by die georganiseerde aktiwiteite van kerke. In lande soos Brittanje, die VSA en Euro- 
pese lande word bereken dat minder as $10 \%$ van die Christene nog kerklik aktief is. In Afrikaanse kerke is kerkbesoek by oggenddienste minder as $30 \%$ en by aanddienste minder as 10\% (vgl. ook Vorster, 1981b:7). Hierdie onkerklikheid moet egter nie noodwendig gesien word as ontkerstening nie. Baie gelowiges ag kerklike betrokkenheid nie meer nodig vir geloofsopbou en Christen-wees nie en sodoende ontwikkel 'n buite-kerklike Christendom (Vorster, 1991:472).

Onttrekking aan eredienste beteken noodwendig onttrekking aan prediking. Minder as $30 \%$ Christene in Suid-Afrika word dus deur die prediking bereik. Op sigself stel die groeiende tendens van buite-kerklikheid 'n groot eis aan die prediking: deur middel van die prediking moet mense oortuig word van die noodsaak van Woordbediening vir geloofsgroei en die uitbou van 'n Christelike lewe.

\section{TOEKOMSANGS EN INTROVERSIE}

Die teenswoordige kultuur van verandering is nie iets wat slegs met die moderne mens gebeur nie; dit is iets wat hyself soek en aanmoedig. Perpetual change bring hoop en uitsig. In verandering lê die sekerheid dat alle ervarings van wanhoop, swaarkry en onderdrukking deur die noodwendigheid van die proses verander moet word; verandering op sigself is die sleutel tot bevryding. Tog blyk dit dat die verandering wat die mens doelbewus najaag sy psige verteer. Toffler (1971:312) sê hieroor:

By indiscriminatcly racing the engines of change, we may be undermining not merely the health of those least able to adapt, but their very ability to act rationally on their own behalf.

Die druk op verandering skep toekomsangs, en wat waar is van die individu is waar van die gemeenskap meen Toffler (1971:332). Die gemeenskap begin ly aan toekomsangs omdat oorstimulasie van verandering, 'n 'bombardement' op die sintuie en 'n oorlading van inligting hom oorweldig. Die moderne mens kan die verandering wat hyself as heilsweg gekies het, nie meer hanteer nie. Hierdie verandering produseer "several common forms of individual maladaptation" (Toffler, 1971:326): die belangrikste hiervan is ontkenning en ontvlugting van realiteite waarvan die mens nie hou nie. "Maladaptation" impliseer onder andere dat die mens spesialiseer in dit waarvan hy hou en die res ontvlug of dat hy met dogmatiese vasberadenheid aan die tradisie klou.

Instead of adapting to the new, he continues automatically to apply the old solutions, growing more and more divorced from reality as he does so (Toffler, 1971:327).

Die kultuur van verandering skep dus 'n gees van toekomsangs en introversie. Dit is presies hierdie tendense wat hulle afspeel binne die teenswoordige Suid-Afrikaanse gemeenskap en waarmee die prediker en die prediking gekonfronteer word. Suid-Afrika beleef ingrypende veranderinge: die wit gemeenskap is uitgeruk uit 'n posisie van bevoorregting en beskerming, die swart gemeenskap beleef interne spanninge en geweld, armoede is duidelik 'n verskynsel wat nog vir lank sy skaduwee oor massas gaan gooi (vgl. hieroor Wilson, 1989). Die veranderingsproses het nuwe realiteite blootgelè 
wat vir die gemiddelde Suid-Afrikaner onoplosbaar lyk.

Die toekomsangs manifesteer in vrees vir die toekoms, angs en diepliggende suspisie en agterdog jeens ander partye op die toneel. Hierdie tendens is duidelik sigbaar in byvoorbeeld die Afrikaanse kerke. Predikante moet lig loop om die onderlinge spanning nie te laat uitbars nie. Dit raak die prediking wesentlik, want die beste manier om die spanning te vermy is om in die prediking ook die realiteite te vermy. Sodoende word die prediking dan algemene stellings oor bo-wêreldse dinge waaroor almal in elk geval konsensus het.

Die introversie manifesteer in ontvlugting van realiteite en 'n krampagtige vashou aan die verlede en tradisionele. Die handhawing van dit wat oud en beproef is word gesien as die wapen teen nuwe realiteite. Hierdie introversie kweek 'n benadering van isolasie waarin die prediker meegesleur kan word: sy prediking kan gevolglik die vorm kry van teologiese regverdiging van die tradisionele weë. 'n Verdere uitvloeisel van hierdie benadering is dat die prediker mense kan leer dat goeie Christenskap die najaag van isolasie beteken. Die implikasie hiervan is dat die Christen hom binne die proses van verandering en konfrontasie moet isoleer van alles wat nuut is. So 'n benadering dra by tot die groei van 'n buite-kerklike Christendom omdat die moderne mens voel dat die prediking hom nie meer persoonlik raak nie.

\section{DIE KUBERNETIESE REWOLUSIE}

'n Ander belangrike aspek van die teenswoordige kultuur van verandering is die sogenaamde kubernetiese rewolusie wat volgens Stott (1981:64) drastiese eise aan die prediking stel. Met die uitdrukking beskryf hy die radikale verandering wat in kommunikasie ingetree het as gevolg van die ontwikkeling van elektroniese media. Toffler (1980:204) sien die koms van die elektronika as die aanbreek van die derde fase in die beskawingsontwikkeling van die mens. Die eerste fase was toe die mens geleer het om landbou te bedryf. Die tweede fase het begin met die Industriële Rewolusie. Die derde fase het nou begin met die ontwikkeling van die elektroniese wetenskap. Hierdie fase is "the third wave" (Toffler, 1980:139).

Die elektroniese media verander die mens se begripsvermoë en dit stel besondere eise aan die prediking wat ' $n$ mondelinge monologiese karakter het. Stott (1981:70) verduidelik die veranderinge so: In sy vroeë ontwikkeling het die mens in stamverband geleef. Kommunikasie het in groepsverband plaasgevind en hiervoor moes die mens al sy sintuie inspan, naamlik gesig, gehoor, reuk, smaak en aanraking. Al hierdie sintuie het ontwikkel. Met die koms van die fonetiese alfabet het die oog die dominante faktor geword in kommunikasie want die mens moes lees en skryf. Die elektroniese era het die gehoor en gesig beklemtoon maar terselfdertyd die behoefte aan deelneming gestimuleer. Die mens sien byvoorbeeld oorlog op televisie maar hy ervaar dit nie self nie. Hy word afgestomp omdat sy ander sintuie nie opgeroep word nie; sy persepsie is onvolledig en belemmer. Stott $(1981: 70)$ is van mening dat televisie die mens 
intellektueel onkrities, emosioneel onsensitief, psigologies verward en moreel gedisoriënteerd maak sodat hy uiteindelik 'n onvermoë tot kommunikasie ontwikkel.

Runia (1983:8) wys ook op hierdie belangrike feit. Hy sè dat die uitvinding van die boekdrukkuns 'n groot verandering gebring het in die mens se vermoë om inligting te absorbeer. Die geskrewe woord het logika gestimuleer deurdat die logiese wyse waarop geskryf is die rasionele in die mens bevorder en die intuitiewe nagelaat het. In dieselfde fase as die boekdrukkuns het die Protestantse prediking ontwikkel en dit het dieselfde trekke vertoon as die skryfkuns. "It too placed much emphasis on the logical, well-developed argument and also appealed to man's rational rather than his intuitive faculty" (Runia, 1983:8). Die elektroniese media het ook verandering in hierdie opsig gebring. Deur middel van elektroniese media word baie stof aan die kyker gegee, maar hy hoef nie meer 'n lang gedokumenteerde argument te absorbeer nie want hy kan self kies waarin hy wel 'deelneem'. Sodoende stomp sy konsentrasievermoë af en hy soek eerder (selektiewe) deelname as die passiewe aanhoor (lees) van inligting. Runia (1983:9) konkludeer:

lt is no wonder that communication thcorists who belicve that this development will continue and even be specded up by the new electronic technology, have a rather low appreciation of the traditional sermon. It secms to belong to a past period. Like the book, it presents its case primarily in a logical sequential, linear fashion and appeals to the rational rather than the intuitive in man.

\section{DIE GEREFORMEERDE PREDIKING IN 'N NUWE MILIEU}

Gereformeerde prediking impliseer brugbou tussen die Bybel en die moderne wêreld (Stott, 1981:135), maar die brug moet aan albei kante stewig veranker wees. In die gereformeerde prediking gaan dit om die Woord, suiwer hermeneutiek en suiwer eksegese. Hierdie primêre gegewenhede is nie hier onder die soeklig nie. Die ander kant van die brug, naamlik die mens en sy wêreld moet wel betrek word. In die lig van die voorafgaande uiteensetting van die kultuur van verandering en die eise wat dit stel, kan die volgende belangrike riglyne getrek word vir effektiewe gereformeerde prediking in 'n nuwe milieu.

\subsection{Gesag}

Vir die moderne mens is alle gesag onder verdenking. Hierop is reeds gewys. Dit gaan naamlik nie meer daarom dat of wat 'n gesagvolle persoon sê nie, maar waarom hy dit sê: sy gesag lề in die motivering en oortuigingskrag van sy saak. "He wants to know why it is worthwhile to believe what the preacher tells him" (Runia, 1983:5). Ten opsigte van die prediking en die prediker is dit nie meer oortuigend om te preek met die rang van 'n predikant of op gesag van die 'kerk' nie. Die mens wil oortuig wees van die hoekom van 'n argument; daarom moet die prediker onderskei tussen valse en ware gesag (Stott, 1981:50).

Valse gesag in die prediking berus op allerlei uitwendige verskansings wat die prediker vir sy eie beskerming oprig soos byvoorbeeld sy geleerdheid, sy amp, sy sinode, sy kerk 
en die algemene opinie. Ware gesag is gesag van Christus wat reëel word in die beloftes en eise van die Woord. Ware gesag is dit wat die Here sê. Daarop staan die prediking en daaruit leef die geloof. Prediking kan niks anders wees nie as bediening van die gesag van Christus en dit is die Woord.

Baie preke klink Skriftuurlik omdat dit in vroom kerklike taal bou aan 'n 'Christelike moraal', maar wanneer nader ondersoek ingestel word, blyk hierdie preke niks anders te wees nie as propaganda van ideologiese vooronderstellings (vgl. hieroor Martin, 1967). Wanneer die predikant dit wat hy preek nie Skriftuurlik kan bewys nie, moet hy liewer swyg, anders misbruik hy die kansel. Bedien hy die gesag van Christus, word hyself en sy eie sieninge klein en hoef hy nie te vrees vir die gevolge van sy prediking nie. Dit gaan dan nie meer om homself of sy posisie nie, maar om die Koning wat praat. Die gereformeerde prediking in die kultuur van verandering sal slaag as die gesag van Christus weer in die prediking herstel word.

\subsection{Kontekstualiteit}

Die prediking moet die mens in sy konteks betrek. Met konteks word bedoel sy leefwêreld met die eise wat dit stel, sy vrese en onsekerheid, sy verwagtinge en ideale, sy drifte en emosies. Die Woord van God moet hom in hierdie konteks motiveer, omkeer en hom in beheer bring van homself. As dit gebeur, sal die prediking nie net vir hom belangrik wees nie, maar onontbeerlik.

Egte kontekstuele prediking vereis deeglike Woordverklaring en verkondiging. Sonder wetenskaplike eksegese en deurgronde teologie kan die prediking nie bestaan nie. Aan die ander kant moet die prediker die konteks van die moderne mens verstaan en daarmee empatie hê. In hierdie opsig skiet die gereformeerde prediking myns insiens ernstig tekort. Aktuele vrae wat in berekening gebring moet word, sluit die volgende in: Verstaan die predikant sy wêreld en die mense om hom? Het hy begrip vir die jongmens wat 'geleef' word deur 'n nuwe moraliteit? Het hy begrip vir die werksman wat deur die groewe van sy beroep ingedraai word in 'n vreemde lewenspatroon? Verstaan hy die gesin wat sukkel om emosioneel en materieel kop bo water te hou? En die belangrikste vraag is: Is die opleiding van gereformeerde predikante sodanig dat dit hom die wetenskaplike middele bied om sy konteks te kan ontleed? 'n Kritiese analise van die ensiklopediese vereistes vir die opleiding van predikante in die Gereformeerde Kerke in Suid-Afrika gee hierop 'n negatiewe antwoord (PU vir CHO, 1992:D 1). Dit skyn asof gereformeerde predikante goed opgelei word om die Skrif te verstaan, maar ongeletterd bly wanneer dit kom by die verstaan van die moderne mens en sy konteks. Hierdie onvermoë bring die gevaar van 'simplisme' na vore: probleme word op 'n simplistiese en ongenuanseerde wyse geanaliseer. So 'n probleemanalise lei noodwendig tot 'n soortgelyke probleemoplossing. Wie al te gemaklik met die probleem omgaan en nie tot die kern daarvan deurdring nie, gee uiteindelik gemaklike oppervlakkige antwoorde waarin die kern van die saak nie betrek word nie. Mense luister nie na preke wat vir ' $n$ ander mens in 'n ander tyd bedoel is nie. Aan hierdie 
aspek van die teologiese opleiding sal dringend aandag gegee moet word as gewerk wil word aan relevante gereformeerde prediking in die toekoms.

\subsection{Kommunikasie}

Die moderne samelewing draai om bestuur en kommunikasie (Toffler, 1980:446). Hierdie twee aspekte kry toenemend aandag in moderne maatskappybeplanning. Ook in Suid-Afrika ondergaan mense hieroor al hoe meer opleiding. Effektiewe bestuur en effektiewe kommunikasie word beskou as die belangrike pilare van gesonde funksionering. Dieselfde mense wat maatskappye beplanningsgeoriënteerd bestuur, is lidmate van kerke. Hulle is ingestel op bepaalde bestuursvorme en ontwikkel 'n oor vir bepaalde kommunikasietegnieke; hulle word geprogrammeer in 'n funksionaliteitsdrif.

Hiermee moet die kerk, die prediker en die prediking rekening hou. As gevolg van hierdie drif verstaan al hoe minder mense die 'lomp werkwyse van die kerk' en die 'monologiese prediking'. In sy beroepsopleiding word die lidmaat immers weggelei van 'n prinsipiële oriëntering na 'n funksionele oriëntering: wat werk is reg. In hierdie gees luister hy na die prediking.

Twee sake is in die lig hiervan vir die prediking belangrik:

- Eerstens moet mense weer geleer word om beginsels te verstaan en te waardeer. Die, prediking van die Woord moet 'n duidelike beginselraamwerk vir die lewe van die gelowige stel: hy moet geleer word om prinsipieel te dink en te doen. Sy lewe moet nie gedryf word deur sy omgewing of die moderne funksionaliteitsdrif nie, maar moet bepaal en gerig word deur die ruggraat van Skriftuurlike beginseldenke. Hierdie denke moet deur die prediking ontwikkel word. In hierdie lig moet die gelowige die eie-aard van prediking raaksien. Stott (1981:15) sê tereg:

No attempl to understand Christianity can suceed which overlooks or denics the truth that the living God has taken the initiative to reveal himself savingly to fallen humanity; or that his self-revelation has been given by the most straightforward means of communication known to us, namcly by a word and words; or that he calls upon those who have heard his Word to speak it to others.

Prediking is nie 'n gepraat oor God nie, maar God wat praat. Van hierdie beginsel kan die gereformeerde prediking hom nie losmaak nie en die moderne mens in sy funksionaliteitsdrif moet geleer word om dit te verstaan. Hy sal dan weer die preek waardeer.

- Tweedens moet die lesse van die moderne kommunikasie genuanseerd na waarde geskat word. Preekkunde kan by die kommunikasiewetenskap baie leer. Juis in 'n kultuur van verandering is kommunikasie en veral oorreding belangrik. Bauman (1920:233) sê dat verandering deur voortdurende oorreding vergesel moet word want " $(p)$ ersuasion is the art of changing people" - 'n feit wat deur die moderne 
kommunikasiekunde aangetoon word. Die prediking moet hierdie kuns bemeester om mense saam te neem in die proses van verandering sodat hulle in 'n nuwe konteks Christene kan wees. Dit is verder wetenskaplik aangetoon dat mense in verskillende ouderdomsgroepe, sosiale omgewing, opvoedingsvlak en omstandighede elk' $n$ bepaalde gerigtheid in die prediking vereis. Binne die beginselraamwerk van gereformeerde prediking moet nuwere kommunikasietegnieke na waarde geskat word. Meer wetenskaplike navorsing hieroor binne die gereformeerde Homiletiek is dringend noodsaaklik.

\section{KONKLUSIE}

Die teenswoordige kultuur van verandering is besig om die Suid-Afrikaanse samelewing ingrypend te wysig en ook die gelowige voel die skokeffek daarvan: sy norme word omgekeer, sy beginsels beproef en sy sekerhede aangetas, hy het nuwe vrae en stel ander eise as gister. Maar in die sterk gety gooi hy nog sy anker uit na God toe. Hy wil God met hom hoor praat. Wie anders kan hom antwoord as die prediker van die Woord? Die vraag is dus nie of daar gepreek moet word nie, maar hó daar gepreek moet word sodat die moderne mens God kan hoor.

\section{BIBLJOGRAFIE}

BAUMANN, D.J. 1990. An Introduction to Contemporary Preaching. Grand Rapids : Baker Bookhousc.

BLOCH, E. 1961. Philosophische Grundfragen I, zur Ontologie des Noch-Nicht-Seins. Frankfurt am Main : Suterkamp Verlag.

BLOCH, E. 1970. A Philosophy of the Future. New York: Herder and Herder.

BULTMANN, R. 1967. Jezus Christus en de mythe. Amsterdam : W. ten Have.

BONHOEFFER, D. 1960 . Concerning the Christian Idea of God. Vol. III. (In Gesammelte Schriften. Müchen : Chr. Kaiser Verlag. p. 25-54.)

DEKKER, G. 1971. Wat is er met de Kerk aan de hand? Over de positie en funksie van de kerk in de huidige samenleving. Kampen : Kok.

DEWAARD, H. 1990. Contextualization. Vox Reformara, 1990(55): 4-10, Nov.

EDWARDS, D L. 1987. The Futures of Christianity. London : Hodder \& Stoughton.

FIERRO, A. 1977. The Militant Gospel. An Analysis of Contemporary Political Theologies. London S.C.M. Press.

GEREFORMEERDE EKUMENIESE SINODE 1988. Acts of the Reformed Ecumenical Synod. Grand Rapids : Michigan. R.E.C.

GEREFORMEERDE KERKE IN SUID-AFRIKA 1991. Memorandum van die Gereformeerde Kerke in Suid-Afrika aan die raad op mededinging oor Sondaghandel. Potchefstroom : Admin. Buro van die GKSA.

HAMILTON, W. 1966. The Death of God Theologies Today. (In Altizer ed. Radical Theology and the Death of God. New York/Kansas City : The Bobbs Merrill Company. p. 70-92.)

HENDRIKS, J. 1986. Vernuwing in bedieningstruktuur. Nederduits Geréformeerde Teologiese Tydskrif, 27(1):72-85, Januarie.

HESSELGRAVE, D J. 1989. Contextualization. Meanings, Methods and Models. Leicester : Apollos.

HEYNS, J A. 1991. Church/State Relations in South Africa (In Alberts, L. \& Chikane, F. eds. The Road to Rustenburg. The Church Looking Forward to a New South Africa. Kaapstad : Struik Christian Books. p. 170-177.)

HULLEY, L. D. 1990. Huidige standpunte van verskillende Suid-Afrikaanse kerke ten opsigte van geweld. (In van der Walt, B.J. red. Venster op mag en geweld. Potchefstroom : IRS / PU vir CHO. p. 67-76.) 
KRITZINGER, K. 1991. Re-evangelizing the White Church. Joumal of Theology for Southem Africa: 106-116, Sept.

MARTIN, A N. 1967. What's Wrong with Preaching Today? Grand Rapids / Michigan : Reformed Fcllowship INC.

MKHATSHWA, S. 1991. Re-evangelizing the Black Church. Joumal of Theology for Southem Africa:117121, Sept.

MOLTMANN, J. 1967. Theology of Hope. London : S.C.M. Press.

POLAK, F L. 1958. De toekomst is verleden tijd. Cultuur-futuristische verkenningen. Zeist : W. de Haan.

PU vir CHO 1992. Jaarboek Fakulteit Teologie. Potchefstroom. PU vir CHO : Dept. Sentrale Publikasics.

ROBINSON, J.A.T. 1968. Honest to God. London : S.C.M. Press.

ROSSMAN, M. 1968. The Two Faces of Youth. Saturday Review: Aug., 17.

RUNIA, K. 1978. Eigentijdse vragen. Kampen : J.H. Kok.

RUNIA, K. 1983. The Sermon under Attack. Exeter : The Paternoster Press.

SoLLE, D. 1965. Plaatsbekleding. Amsterdam : Ten Have.

STOTT, J.R.W. 1982. I Believe in Preaching. London: Hoddcr \& Stoughton.

STOTT, J. 1984. Issues Facing Christians Today. Hauts : Marshalls.

TOFFLER, A. 1971. Futurc Shock. London : Pan Bonks Lid.

TOFFLER, A. 1980. The Third Wave. London : William Collins.

VORSTER, J.M. 1981a. Die kerk cn dic klcurvraagstuk vandag. Johanncsburg : De Jongh Uitgewers.

VORSTER, J.M. 1981b. Het die kerk nog betekenis? Pretoria : N G Kerkbockhandel.

VORSTER, J.M. 1991. Buite-kerklikheid en makro-kerklikhcid in dic moderne Ekklesiologie. In die Skriflig, 25(4):471-483, Desember.

VOSLOO, W. \& BISSCHOFF, J.H. 1989. Belewenisse en bchocftes van predikante. Nederduits Gereformeerde Teologiese Tydskrif, 30(4):563-573, September.

WILSON, F. 1989. Uprooting Poverty. The South African Challenge. Johannesburg : David Philip. 
